\title{
Complaints and troubles talk about the English language skills of international students in Australian universities
}

\author{
Michael Haugh \\ Griffith University
}

\begin{abstract}
:
International students have continued to be the focus of simplistic stereotyping in media discourse where they are frequently identified as one of the forces behind declining academic standards in Australian universities. Their English language skills, in particular, have continued to be the focus of debate both in the mainstream media and in higher education research and policy. It is argued in this paper, however, that such debates do not sufficiently acknowledge the moral and affective complexity of the so-called "English problem" amongst international students in Australian universities. Drawing from an analysis of small group interviews with international students, domestic students and university staff, the beliefs and experiences of various parties about the English language skills of international students are examined. A key finding from this analysis is that the English language skills of international students, and their concomitant interactions with others, can be the object of both complaints and troubles talk. These complaints or troubles can be either ratified or resisted by those participants. The difficulties international students may experience in using English thus have complex moral and affective consequences. The way in which the so-called English problem in Australian universities is generally couched as one of objective, measurable deficiency on the part of international students arguably neglects the moral and affective complexity of the difficulties facing international students. This neglect leads, in turn, to an impoverished understanding of the English language capabilities of international students.
\end{abstract}

\section{Keywords:}

international students, English proficiency, identity, complaint, troubles talk

\section{Word count:}

6818 


\section{Complaints and troubles talk about the English language skills of international students in Australian universities}

\section{Introduction}

For the past three decades the number of international students in Australia's higher education sector has grown exponentially from approximately 13,700 in 1983 to nearly 250,000 enrolments in 2014 (Australian Education International, 2014; Burke, 2002). There has also been a corresponding growth in discourses on problems in relation to international students studying in Australian universities, both in the popular media and amongst academic researchers. Many of these discourses have been arguably negative, ranging from talk of international students as "backdoor migrants" and "invaders" through to references to them as "cash cows" or "commodities". Such discourses have, in turn, been resisted by some, notably international students themselves (Burke, 2002, 2012; Robertson, 2011).

One discourse, in particular, has dominated such debates, namely, the so-called "English problem.” This discourse involves ongoing claims that international students have inadequate English language skills for participating in academic studies, and graduate with insufficient English language skills for subsequent employment in Australia. It is argued that this not only reflects, but has also led to academic standards falling in Australian universities (Birrell, 2006; Coley, 1999; Phillips 1987). As Benzie (2010) points out, however, the stereotype of international students having inadequate English language skills which has emerged, "ignores the many international students who do have adequate English language levels and perform well” (p.449). Devos (2003) also argues that there has been a tendency to over-generalise in media discourse about international students. Yet debates in the Australian media about the English problem vis-à-vis international students and declining academic standards have not abated (Linton \& Bessar, 2015).

The view that many international students have inadequate English language skills is one that has also gained considerable traction in influencing recent governmental and institutional policies, including those relating to entry standards and subsequent English language support for international students (Arkoudis, Baik \& Richardson, 2012; DEEWR, 2009; Bradley et al., 2008). Indeed, numerous studies have indicated that the level of English language proficiency of international students, at least as measured by various formal tests of proficiency, impacts on their degree of academic achievement (e.g. Craven, 2012; Donohue \& Erling, 2012; O’Loughlin \& Arkoudis, 2009; cf. Humphreys, Haugh, Fenton-Smith, Lobo, Michael \& Walkinshaw, 2012). Even perceptions of inadequate English language proficiency amongst international students have been found to negatively impact on their level of academic achievement (Barker, Child, Gallois, Jones \& Callan, 1991), as well as on their degree of psychological or emotional well-being (Robertson, Lines, Jones \& Thomas, 2000; Tananuraksakul \& Hall, 2011). However, such policies have often been premised on a deficit view of international students. That is, where they are cast as having inadequate language skills, and that this problem needs to be addressed through various means of English language support (Benzie, 2010). In studies of the perceptions of international students themselves, the English problem is also often couched in terms of inadequate proficiency in one or more of the four skills (listening, reading, speaking, writing), alongside knowledge of 
specialist vocabulary or academic genres (Briguglio \& Smith, 2012; Leder \& Forgasz, 2004; Zhang \& Mi, 2010). It is thus commonly assumed that if international students are given sufficient English language support targeting the four skills in academic contexts (Benzie, 2010; Murray, 2012; Robertson et al, 2000), the problem of falling academic standards in Australian universities will be ameliorated, if not outright arrested.

In this paper, it is argued that such views over-simplify the complex affective and moral terrain of perceptions of, and about, international students. Drawing from small group interviews, the following discussion focuses on beliefs and experiences of, or about, international students in Australian higher education, including the difficulties they experience in using English. These difficulties are analysed building on approaches in pragmatics and ethnomethodological conversation analysis that theorise identity and social action as fundamentally interactional phenomena (Haugh 2012). It is now well established from ongoing research that we can study the ways in which participants express and respond to difficulties through the lens of either troubles talk or complaints (Boxer, 1993; Drew, 1998; Jefferson, 1988). Talk about such difficulties can also ground the co-construction of identities by participants (Haugh 2008, 2015). Yet while both troubles talk and complaints involve expressing some degree of dissatisfaction or discontent with a particular situation, they differ in the object of that dissatisfaction or discontent.

In the case of troubles talk, the focus is on "the teller and his [or her] experiences" (Jefferson \& Lee, 1981, p.411). For example, in the following excerpt, an international student from Korea talks about the troubles he has in expressing himself in class, and the frustration this causes for him.

(1) G8: $13: 30$

K4: I came here for studying Tourism and Hotel Management. Actually, uhm I, I think I know so many things about management things in, in hospitality field. For example, marketing, financial control, or managing skills or something like that. But the only problem is I can't express my knowledge, my thoughts. Actually, I really want to talk about so many things, I got so many things behind. But I can’t express my real- especially in tutorial class.

Complaints, on the other hand, involve construing that dissatisfaction or discontent as a form of moral transgression on the part of someone else (Drew, 1998). This involves the speaker attributing responsibility for that state of discontent to a particular individual or a group of individuals (Heinemann \& Traverso, 2009). For example, in the following excerpt, an international student from Japan complains that he wasn't given sufficient opportunities to speak in class, and this adversely affected his final grade.

(2) G7: 43:35

In one class I went to class on time every week, but I got zero for participation, so I went to ask the lecturer and he said that I didn’t participate. That was very hard because I prepared my homework, and prepared what to say, but the lecturer didn’t give me a chance to speak.

A key finding from the analysis of complaints and troubles talk about the English language skills of international students, and their concomitant interactions with others, was that participants themselves do not treat or respond to them in the same way. This is largely a 
consequence of the different moral implications of the two social practices. While troubles talk centres on expressions of affect, complaints involve an expression of moral indignation. Discourses on international students, however, tend to conflate the two. This has led, it will be argued, to an impoverished understanding of the English language capabilities of international students.

In the next section, the dataset and methods are introduced. This is followed, in section three, by a preliminary analysis of international student identities, which emerged through content analysis of the small group interview data. Three key focal points of these identities were found to be appreciations, complaints, and troubles talk. In section four, building on an interactional analysis of the ways in which participants formulated and responded to complaints and troubles talk, it is argued that these are inherently moral actions. It is suggested, in particular, that there are differences in the extent to which various stakeholders hold themselves and others accountable for the perceived difficulties of international students. The implications of this analysis for academic research, as well as broader policy debates on international students are then briefly considered in the final section.

\section{Data and method}

A total of eleven small group interviews were conducted with international students from a large Australian university that has a significant proportion of international students. Participants included 31 undergraduate students from a variety of countries, including Brazil, Chile, China, India, Iran, Japan, Korea, Russia, Taiwan and Thailand. These were supplemented with four small group interviews with local students, academic staff and administrative staff from the same university. The interviewers followed a semi-structured interview format in asking international students about their experiences studying at the university in question, and in asking the other participants (i.e. local students, academic staff and administrative staff) about their experiences with international students at that university. All of the interviews were carried out by research assistants who have experience teaching international students, rather than the author himself. ${ }^{1}$

The interview data was analysed using content analysis (Krippendorff, 2013), specifically, a constructivist grounded theory approach (Charmaz, 2000). Claims made by, and about, international students were first identified and coded in an open-ended fashion. This preliminary analysis was carried out independently by the author and a research assistant. $^{2}$ The various claims identified were then grouped by the author through axial coding into expressions of appreciation, complaints, and troubles talk. Finally, given the importance placed on international student identities in the research literature, the Communicative Theory of Identity (Hecht, 2009) was selected as the conceptual lens through which to carry out selective coding of the data.

According to the Communication Theory of Identity, identities are accomplished through communication in four interpenetrating frames:

\footnotetext{
${ }^{1}$ The author has taught international students in both English language courses and in classes in linguistics where they are part of a larger cohort involving local students. He has also been an international student himself in the past, studying in a second language in Japan.

${ }^{2}$ The author would like to thank Louie Dragut for his assistance in identifying these initial themes.
} 
(a) personal (i.e. "the ways an individual conceives of self”)

(b) enacted ("the performance or expression of identity")

(c) relational ("identities that are invested in relationships, exist in relationship to each other, and are ascribed in and through relationships")

(d) communal (identities that "exist as characteristics of communities...held in common by groups rather than individuals").

(Hecht, 2009, p. 140, original emphasis)

The beliefs and experiences reported by the participants were thus classified according to the frame of identity they were enacting on their own behalf and/or on the behalf of others. The validity of the themes that were identified in the course of this analysis was premised on the extent to which the other participants themselves ratified, qualified or disputed the claimed or attributed identities in question (Author, 2008).

A key finding from the content analysis of the small group interviews was that complaints and troubles talk were an important vehicle through which international student identities were managed by the participants. This motivated, in turn, a subsequent round of close interactional analysis (Author, 2012). The expression of some degree of dissatisfaction or discontent with a particular situation by a participant was examined with respect to whether it developed into troubles talk or a complaint. The responses of other participants to that (incipient) troubles talk or complaint were also analysed. Twenty sequences involving troubles talk and complaints were transcribed following conversation analysis conventions in order to facilitate this analysis (Jefferson, 2004).

\section{Construing international student identities through appreciations, complaints and troubles talk}

The participants in the small group interviews reported a number of beliefs about, and experiences either as or interacting with international students. Through content analysis of these reported beliefs and experiences three broad themes emerged with respect to the Communicative Theory of Identity. These include the way in which the personal, relational and communal identities of international students were construed as sources of appreciations, complaints and troubles talk. These three themes are summarised in Table 1 below. $^{3}$

\begin{tabular}{|l|l|l|l|}
\hline & Troubles talk & Appreciations & Complaints \\
\hline Personal & $\begin{array}{l}\text { - lacking confidence } \\
\text { - stress and frustration }\end{array}$ & & \\
\hline
\end{tabular}

\footnotetext{
${ }^{3}$ Only those themes that were found to recurrently occur across the interviews were included. Frequency counts are not included, however, as the sample size was not deemed large enough to warrant generalisations across stakeholders in the higher education sector. The aim of this section is thus to illustrate the kinds of complaints and troubles raised by the participants, not to make claims as to the extent to which these might occur across larger populations.
} 


\begin{tabular}{|l|l|l|l|}
\hline Relational & $\begin{array}{l}\text { - difficulties using English } \\
\text { with locals }\end{array}$ & $\begin{array}{l}\text { - sympathetic/helpful } \\
\text { treatment by academic and } \\
\text { administrative staff } \\
\text { - sympathetic/engaged } \\
\text { treatment by local students }\end{array}$ & $\begin{array}{l}\text { - unsympathetic/contemptuous } \\
\text { treatment by academic staff } \\
\text { - unsympathetic/unhelpful } \\
\text { treatment by administrative } \\
\text { staff } \\
\text { - ignored or snubbed by local } \\
\text { students }\end{array}$ \\
\hline Communal & $\begin{array}{l}\text { - lacking confidence } \\
\text { - stress and frustration }\end{array}$ & & $\begin{array}{l}\text { - target of contempt and } \\
\text { discrimination }\end{array}$ \\
\hline
\end{tabular}

Table 1: Loci of troubles talk, appreciations and complaints by and about international students

The first theme encompassed claims centred on the personal frame of identity, that is, reports that involved the self-concepts or self-images of individuals. One recurrent claim was that many international students lack confidence in speaking English in various spheres of interaction. These include in-class interactions with lecturers, tutors and other local students, interactions with local students and administrative staff outside of classes, as well as interactions with members of the broader community in which they live. The following excerpt is illustrative of such reports. ${ }^{4}$

(3) G4: 28:55

HK1: I have some friends that they even don't, when they, like, go to McDonalds and they want to buy a meal, they just say "Oh, can you help me? Can you help, ah, me to buy meal number 1, for the chicken?”, something like that “Because I don’t want to speak to the uhm staff in English”, something like that. So they, because their English is not so good, so they feel very embarrassed in speaking before a English speaker. They, they are afraid that they will be laughed by them, or something like that.

This lack of confidence, and related perceived inadequacy in communicating in English was associated with a second recurrent claim, namely, that their English language skills were a source of emotional stress and frustration in different types of interaction. An example of this is illustrated in the following excerpt.

(4) G9: 8:05

C3: Maybe the different culture and different emotion express style, so I feel, I feel difficult to understand local, both the language and the culture. I think I need time to adjust that.

In this way, then, the participants enacted on behalf of themselves, or on behalf of other international students, a personal frame of identity as lacking in confidence in their ability to interact in English with local students and academic staff, as well as with members of the broader community. In some cases, they also cast themselves as having an inadequate level of English language skills in the context of academic interactions.

The second theme encompassed claims centred on the relational frame of identity, namely, various ways in which international students were cast vis-à-vis their relationships with others. On the one hand, international students reported that local students and academic

\footnotetext{
${ }^{4}$ Participants in the small group interviews are identified as follows: the interviewer is identified by "I"; international students are identified by codes for nationality (HK: Hong Kong; K: Korean; J: Japanese; C: Mainland Chinese; T: Taiwanese; R: Russian) and number (e.g. HK1); academics are coded by "A” and number (e.g. A1), and local students are coded "LS” and by number (e.g. LS1).
} 
staff showed empathy and understanding for the difficulties communicating in English they sometimes faced, as can be observed in excerpt (5).

(5) G7: 19:19

J5: You know cause in Australia no one really cares what you are doing. I think that they do, but they are very easy going, like they are very helpful, like.

I: You mean you don't get like criticised you don't get looked down upon or.

J5: Like whenever you make a mistake that's fine.

Through such reports, the participants enacted identities where international students are construed as being in sympathetic and understanding relationships with local students and academic staff.

On the other hand, other reports by participants involved rather more negative experiences in relating with others. These included interactions where international students reported feeling they were the target of contempt, discrimination or disrespect from academic staff, local students and administrative staff. Excerpt (6) is illustrative of reports attesting to these kinds of negative experiences.

(6) G7: 58:43

J6: She is very nice, to Australian. But uhm, she's. There is one Chinese girl who is having difficulties with assignments. And she is not good at speaking English, so it takes time. But the- you know, tutor or lecturer, kind of gives them that face, bad looking, "Okay so what are you trying to say?”, well I understand, but you know. I have seen that situation, so I, from that time, I didn't want to ask her any questions to her cause its very- I was very afraid that, that I will give her a really difficult time, you know, I don't want her to hate me or anything because of my English skills.

In this way, then, the participants also cast international students as sometimes experiencing unsympathetic and contemptuous relationships with local students and staff where they were snubbed or were even the target of (perceived) discrimination. ${ }^{5}$

A third theme encompassed claims centred on the communal frame of identity, that is, ways in which participants cast themselves and others as belonging to a larger body of international students. In some cases these centred on their troubles with English, and the stress this causes them, as we can see in the following excerpt.

(7) G4: 13:15

HK1: International students they always, they afraid of speaking out in front of other people, especially in front of the domestic students. They think their English is not good enough. They will be embarrassed.

In other cases, these communal identity claims centred on complaints about being targets of contempt and discrimination.

(8) G4: 6:30

HK1: In the tutorial we just separate, I think we have a little bit discriminate by them, because maybe they think our English is not good enough to complete the assignment with a good grade. Uhm, so they always, not all I mean, but most of the domestic students they will refuse to have a group with us.

\footnotetext{
${ }^{5}$ See Haugh (2015) for further elaboration of this theme.
} 
One notable tendency to emerge in the course of this analysis was that personal frames of identity were largely achieved through troubles talk (e.g. lacking confidence in speaking English; communicating in English as source of emotional stress and frustration). Relational and communal frames of identity, on the other hand, were enacted through both troubles talk (e.g. international students as recipients of empathy for their perceived difficulties in communicating in English), and complaints (e.g. international students as targets of contempt and abuse for perceived inadequacies in English language skills). Prior work on troubles talk and complaints has indicated that these involve different affective and moral claims, and so they can be oriented to in different ways by participants. In the following section, we thus move to examine more closely the ways in which participants both affiliated and disaffiliated with instances of (incipient) troubles talk and complaints.

\section{4. (Dis)affiliating with complaints and troubles talk}

Complaints and troubles talk involve participants expressing some degree of dissatisfaction or discontent with a particular situation. They differ, however, with regard to the object of that expression of dissatisfaction or discontent. In the case of troubles talk the object is wholly affective, while in the case of complaints the object of discontent is not only affective but involves a (perceived) moral transgression on the part of a particular individual or group of individuals. Participants orient to these different affective and moral implications through the way in which they respond to prior talk. Responses may be either affiliative, that is, where the recipient displays support or empathy for the affective stance of the speaker, or disaffiliative where support or empathy is not displayed (Lindström and Sorjonen, 2013). In the case of troubles talk, a troubles-recipient can either affiliate with those troubles through displaying emotional reciprocity, or disaffiliate with them through offering advice or attempting to shift the topic away from those troubles (Jefferson, 1984, 1988; Jefferson \& Lee, 1981). On the other hand, an affiliative response to a complaint involves a complaintrecipient indicating agreement with the moral stance embodied in the complaint, while a disaffiliative response involves construing the complaint as unwarranted through (implicitly) resisting or rejecting the grounds for the complaint (Drew \& Walker, 2009), or alternatively, offering advice.

The different responses to troubles talk and complaints are summarised in Figure 1.

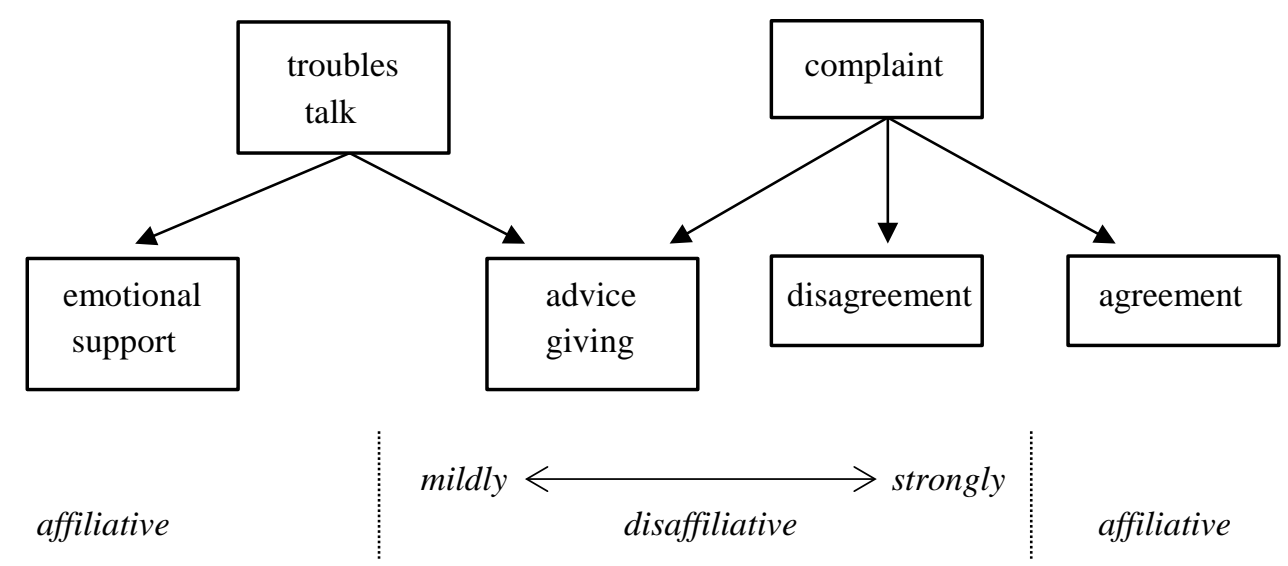


Figure 1: (Dis)affiliative responses to troubles talk and complaints

In the course of analysing the responses of participants to these perceived troubles talk or complaints, it became evident that while troubles talk largely occasioned affiliative responses (8/10 cases), complaints largely occasioned disaffiliative responses (8/10 cases). In other words, expressions of dissatisfaction or discontent that were construed as troubles talk invariably elicited displays of empathy or sympathy from other participants. However, when such expressions of dissatisfaction or discontent were construed as complaints they were more commonly resisted or disputed.

Given the evidently delicate and morally complex nature of complaints, it is to a close analysis of responses to (perceived) complaints by, and about, international students that we now turn. In the following excerpt from a group interview involving three international students from Taiwan (T1-3), for instance, a shared complaint about the way in which international students are excluded by local students is progressively enacted, and affiliated with, by the three participants.

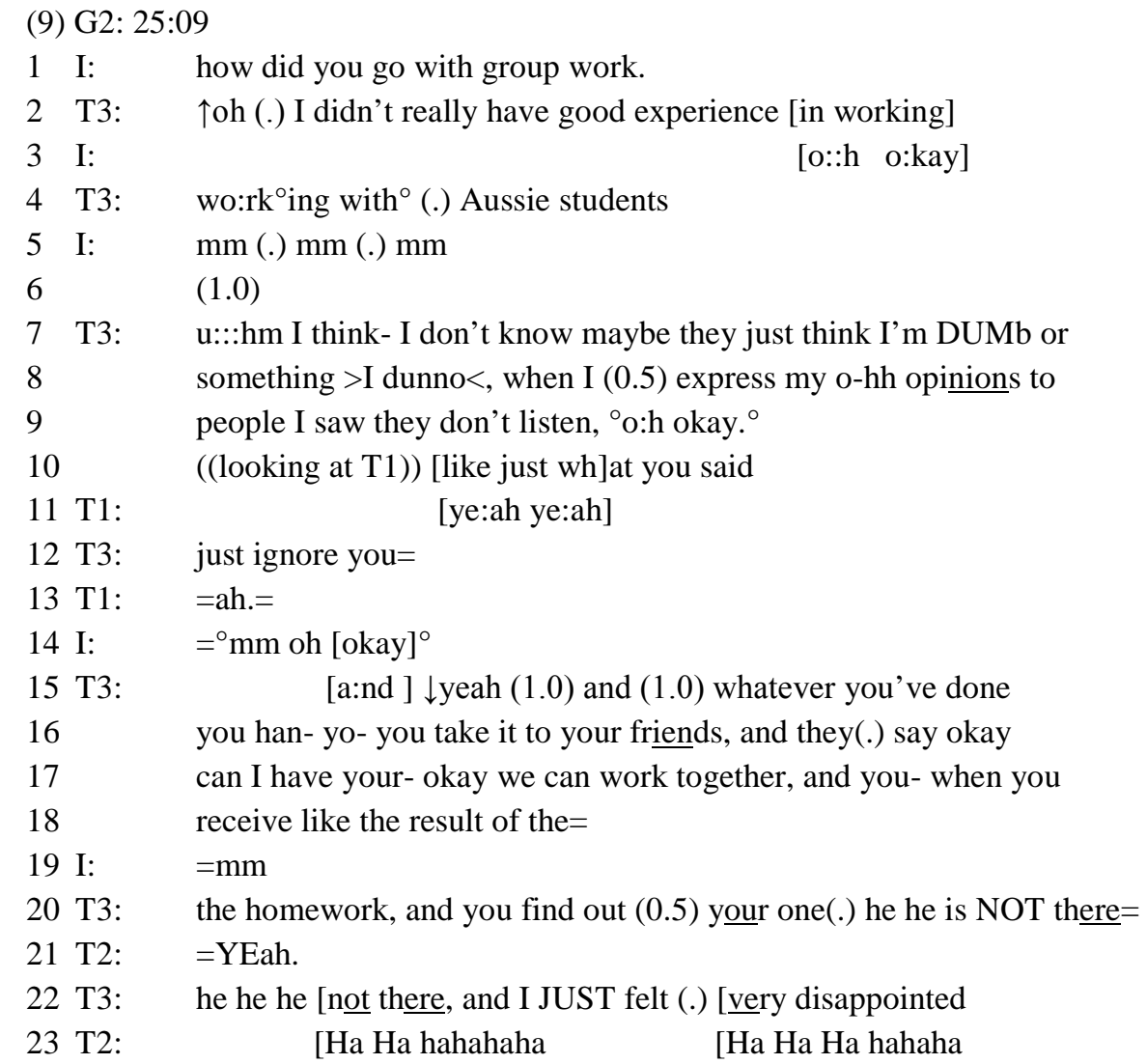

In lines 2 and 4, T3 alludes back to a complaint made by T1, namely, that they are excluded by local students when doing group assignments. T1 displays emphatic agreement with (line 11), and recognition of (line 13) this complaint (cf. Author, 2008, p. 215). As T3 elaborates in reporting on her negative experiences, and thereby implements an implicit complaint that her contributions are ignored and rejected by local students, T2 also displays emphatic agreement (line 21), followed by affiliative laughter (line 23). In this way, then, the three participants 
enact a joint footing as co-complainants. Through affiliating with the moral stance enacted through the complaint, namely, that this exclusion is unfair and insulting and so constitutes a moral transgression on the part of local students, the complaint itself is treated by the participants as warranted. Notably, the blame for this is implicitly laid with the attitudes of local students rather than any perceived difficulties in communicating in English by the international students in question.

However, while such complaints did occasion affiliative responses in two instances, in most cases they prompted disaffiliative responses. Prior to the following excerpt from a group interview that involved two Japanese (J5, J6), a Korean (K1) and a Russian (R2) international student, for example, the Korean student has been complaining that the English language support offered by the university is inadequate. She goes on to elaborate the object of her complaint, namely, that academic staff at the university did not offer help or advice when she asked about improving her English language skills, but instead told her to go and enrol in a TAFE course (cf. Author, 2008, p. 217). She concludes that this reflected a lack of concern on the part of those academic staff, not only for her difficulties in studying in English, but also for her desire to improve her perceived level of English language proficiency. The excerpt begins at the point the other participants respond to this complaint.

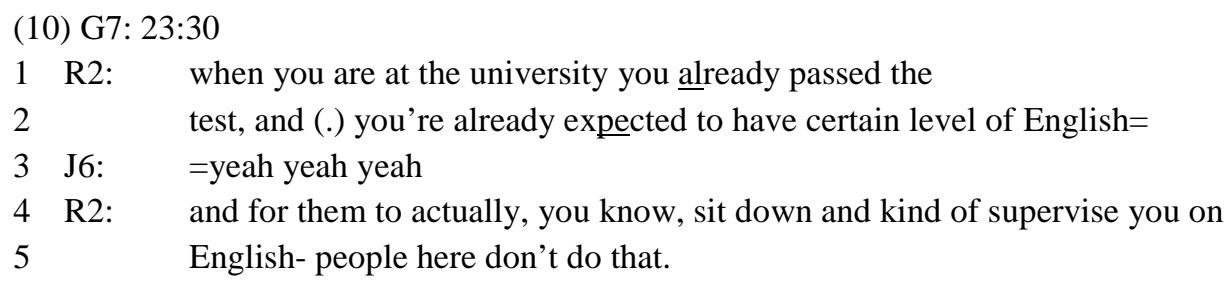

The Russian international student here responds to the Korean student's complaint by claiming that one is expected to have a certain level of English at the point one enters university (lines 1-2), and so academic staff do not need to offer assistance with improving English language skills (lines 4-5). R2's response is thus disaffiliative as she undermines the warrant for the Korean student's complaint. Notably, another student (J6) also affiliates with R2's disaffiliative response. In this way, they co-construct a joint stance that the lack of assistance with writing offered by academic staff, about which K3 is complaining, does not constitute a moral transgression. Their stance is that her troubles with communicating in English are primarily her responsibility now that she is enrolled at university.

Complaints about international students were also found to occasion disaffiliative responses. However, rather than overtly disaffiliating with such complaints, participants reframed these expressions of dissatisfaction or discontent as more appropriately the focus of troubles talk rather than complaints. In the following excerpt from a group interview with two academic staff (A2, A3), for instance, one of academic staff members is elaborating on discontent amongst other academic staff about international students "not speaking out in class."

(11) G12: 10:38

1 A2: a::h (0.4) sometimes oral presentations but mostly group work.

2 so often people not speaking out in class is the issue. 


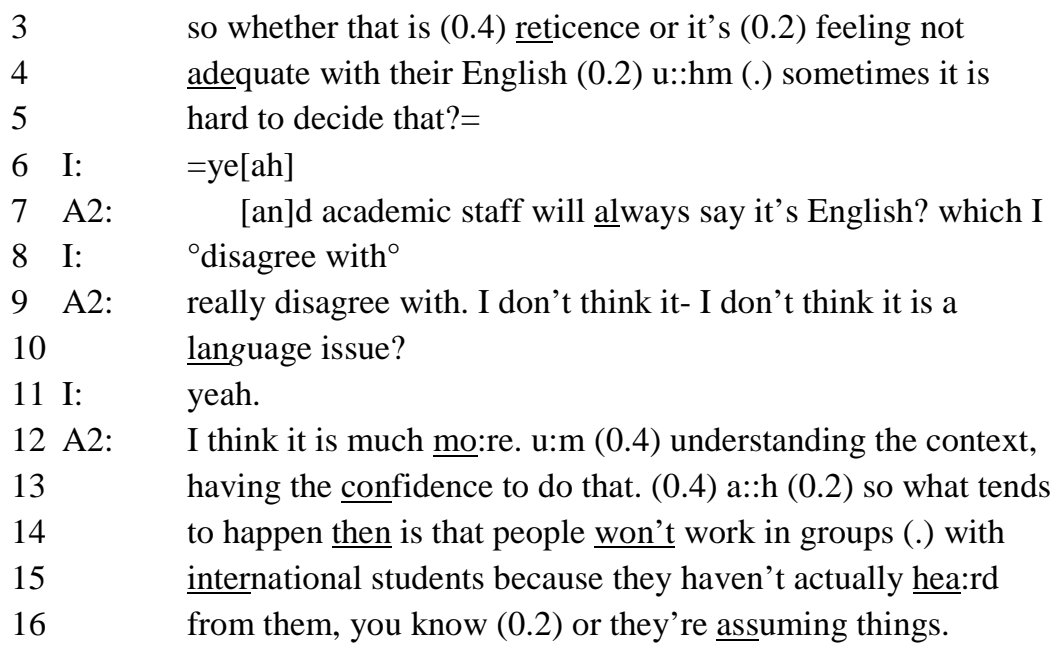

The way in which international students are perceived by academic staff as not participating appropriately in classes and oral presentations is here is treated as a complainable (Schegloff, 2005). A2 claims that most academic staff lay the blame for this state of affairs on the inadequate English language skills of international students (lines 7, 9-10). However, she herself construes this "not speaking out" as troubles on the part of international students themselves that arise through being shy or lacking confidence (lines 3-5). She goes on to suggest that this lack of confidence is interpreted by local students as a lack of ability to communicate in English (lines 12-16). In this way, the participant disaffiliates with the complaint about international students attributed to other academic staff by undermining the warrant for their claim that the English language skills of international students are the problem. She also reframes the complainable in question as more properly the focus of troubles talk, where the lack of interaction between international and local students is understood as problematic from the perspective of institutional policies on internationalisation.

The reframing of complainables as more properly understood as troubles was also evident in the following excerpt taken from a group interview with two local students (LS1-LS2). The interviewer brings up the issue of how the two local students deal with cases where they are involved in group work with international students.

\begin{tabular}{|c|c|c|}
\hline \multicolumn{3}{|c|}{ (12) G10: 8:20 } \\
\hline 1 & $\mathrm{I}:$ & what about the sticky issue of a::h of course international \\
\hline & & students ma::y (0.2) when they're doing their writing, and \\
\hline & & you're put together if do a group essay and so on $(0.2)$ how \\
\hline & & do you sort of deal with that issue, have you faced that issue? \\
\hline & LS1: & $\underline{\text { u}}::::$ m (0.4) ye:ah a bit. but I didn’t- I didn’t really mi:nd (0.2) \\
\hline & & u:m (0.6) a:h like correcting it and tinkering with the grammar \\
\hline 7 & & and stuff [when they did mine \\
\hline 8 & I: & {$\left[{ }^{\circ} \mathrm{oka}: \mathrm{y} \mathrm{yeah}^{\circ}\right.$} \\
\hline & LS1: & because I suppo:se as a language lea:rner I understand how it is \\
\hline 10 & & (.) from the [other si:de? \\
\hline & $\mathrm{I}:$ & [yeah okay \\
\hline & LS1: & so: $(0.2)$ yeah $(0.2)$ he he \\
\hline & LS2: & I think it's the same we we- (0.4) I guess (.) we're in a position \\
\hline
\end{tabular}




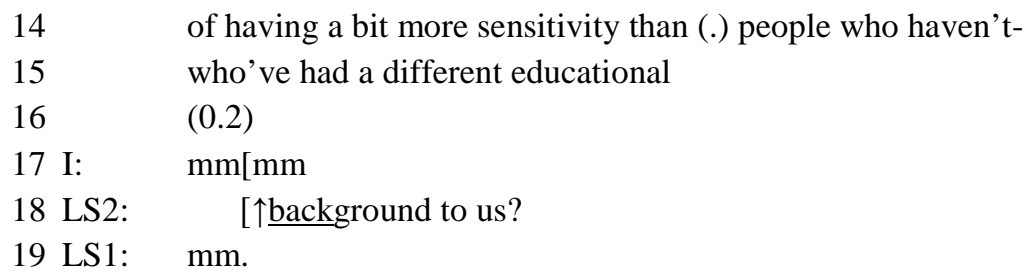

In lines 1-4, the interviewer formulates working with international students as a complainable. However, LS1 disaffiliates with the claim that working with international students could constitute a point of complaint (lines 5-7). Instead, she goes on to construe difficulties with the mechanics of writing as a source of trouble in alluding to her own troubles as a learner of another language, and going on to display empathy for international students who experience such troubles (lines 9-10). The other participant, LS2, affiliates with LS1's construal in also construing these difficulties as troubles that should prompt empathy and understanding on the part of local students (lines 13-15, 18), a position which is then subsequently reiterated by LS1 (data not shown). In this way, then, the two participants jointly co-construct a stance of empathy and understanding with the troubles of international students vis-à-vis English language skills, rather than treating them as objects of complaint. They do, however, allude to their belief that other local students may not share their stance (lines 14-15, 18). They suggest that latter's complaints are due to them lacking experience in learning languages, thereby implicitly undermining the moral grounds for their complaints about international students.

In this section, it has been suggested that the way in which troubles talk occasions largely affiliative responses, while complaints occasion largely disaffiliative responses, is a consequence of the moral implications of the latter. More specifically, while both troubles talk and complaints involve the affective expression of dissatisfaction or discontent, complaints involve treating this dissatisfaction or discontent as arising through the actions of others, which are thereby claimed to constitute moral transgressions. It is the delicate nature of such moral claims that prompts, it would seem, this broad range of disaffiliative responses alongside the affiliative responses that were also observed in these small group interviews.

\section{Conclusion}

The rapid rise in the numbers of international students enrolled in Australian universities over the past three decades has been accompanied by a rise in discourse where the English language skills of international students are problematised as inadequate and the cause of falling academic standards. Increased awareness of such issues has prompted the implementation of policies both at national and institutional levels to provide greater English language support for international students. There is evidently an ongoing discourse where dissatisfaction and discontent about the English language skills of international students is expressed by various stakeholders. However, in this paper it has been argued that these expressions of dissatisfaction or discontent can be construed in two quite different ways as either troubles talk or as complaints. Notably, being construed as troubles talk, as opposed to complaints, was critical with respect to what kind of response the expression of dissatisfaction or discontent occasioned from stakeholders. It was found that construing the 
so-called English problem as a focus of troubles talk prompted largely affiliative responses. However, construing such as issues the focus of complaints prompted largely disaffiliative responses, where the moral grounds for making such complaints were disputed or implicitly resisted. Perceptions of the English problem are evidently multi-layered and morally complex, not only for international students themselves, but also for other stakeholders, including local students, academic staff and administrative staff. There is thus currently a disconnect between the moral complexity of the perceptions of stakeholders themselves, and the way in which the so-called English problem in Australian universities is couched as one of objective, measurable deficiency in discourses about international students. The latter has arguably resulted in an impoverished understanding of the English language capabilities of international students.

The upshot is that any analysis of the perceptions of international students, local students, academic staff, administrative staff or members of the broader community with respect to the English language skills of international students needs to carefully analyse how expressions of dissatisfaction or discontent are construed by those participants. Indeed, it may prove instructive to track the relative frequency of troubles talk versus complaints with respect to international students over time, as this may serve as a useful indicator of the relative efficacy of measures undertaken to support English language development amongst international students. It would also advisable for local students as well as academic and administrative staff to be made more aware of the troubles of international students, rather than simply seeing them as objects for complaint. In addition, it would be useful to draw greater attention to policy makers in higher education to the moral complexity of the ongoing discourse of complaint about the English language skills of international students. In this way, we can move beyond the view that the so-called English problem is simply a matter of an objective, measurable deficiency on the part of international students.

\section{References}

Arkoudis, S., Baik, C., \& Richardson, S. (2012). English Language Standards in Higher Education. Victoria: ACER Press.

Australian Education International. (2014). International student enrolments in Australia 1994-2014. Retrieved from https://internationaleducation.gov.au/research/InternationalStudent-Data/Pages/InternationalStudentData2014.aspx.

Barker, M., Child, C., Gallois, C., Jones, E., \& Callan, V. (1991). Difficulties of overseas students in social and academic situations. Australian Journal of Psychology, 43(2), 7984.

Benzie, H. (2010). Graduating as a 'native speaker': international students and English language proficiency in higher education. Higher Education Research and Development, 20(40), 447-459.

Birrell, B. (2006). Implications of low English standards among overseas students at Australian universities. People and Place, 14(1), 53-64.

Boxer, D. (1993). Complaining and Commiserating. Berlin: Peter Lang.

Bradley, D., Noonan, P., Nugent, H., \& Scales, B. (2008). Review of Australian Higher education: Final report. Department of Education, Employment and Workplace 
Relations (DEEWR). Retrieved from

http://www.innovation.gov.au/highereducation/ResourcesAndPublications/ReviewOfAus tralianHigherEducation/Pages/ReviewOfAustralianHigherEducationReport.aspx.

Briguglio, C., \& Smith, R. (2012). Perceptions of Chinese students in an Australian university: are we meeting their needs? Asia Pacific Journal of Education, 32(1), 17-33.

Burke, R. (2002). Invitation or invasion? The 'family home' metaphor in the Australian media's construction of immigration. Journal of Intercultural Studies, 23(1), 59-72.

Burke, R. (2012). Contesting notions of an 'education industry': media commentary on the transition to a trade-orientated international student program in Australia. Flinders Journal of History and Politics, 28, 141-174.

Charmaz, K. (2000). Grounded Theory: Objectivist and Constructivist Methods. In N. K. Denzin \& Y. S. Lincoln (Eds.), Handbook of qualitative research ( $2^{\text {nd }}$ edn) (pp.509-535). Sage, Thousand Oaks, CA.

Craven, E. (2012). The quest for IELTS 7.0: investigating English language proficiency of international students in Australian universities. IELTS Research Reports, 13 (Report 2). IELTS Australia. Retrieved from http://www.ielts.org/PDF/vol13_Report2.pdf.

Coley, M. (1999). The English language entry requirements of Australian universities for students of non-English speaking background. Higher Education Research \& Development, 18(1), 7-17.

DEEWR. (2009). Good Practice Principles for English Language Proficiency for International Students in Australian Universities. Department of Education, Employment and Workplace Relations (DEEWR). Retrieved from

http://www.innovation.gov.au/highereducation/ResourcesAndPublications/HigherEducat ionPublications/OtherPublications/Pages/GoodPracticePrinciples.aspx.

Devos, A. (2003). Academic standards, internationalisation, and the discursive construction of "the international student". Higher Education Research \& Development, 22(2), 155166.

Donohue, J. \& Erling, E. (2012). Investigating the relationship between the use of English for academic purposes and academic attainment. Journal of English for Academic Purposes, 11(3), 210-219.

Drew, P. (1998). Complaints about transgressions and misconduct. Research on Language and Social Interaction, 31(3/4), 295-325.

Drew, P., \& Walker, T. (2009). Going too far: Complaining, escalating and dissafiliation. Journal of Pragmatics, 41(12), 2400-2414.

Haugh, M. (2008). The discursive negotiation of international student identities. Discourse: Studies in the Cultural Politics of Education, 29(2), 207-222.

Haugh, M. (2012). Conversational interaction. In K. Allan \& K. M. Jaszczolt (Eds.), The Cambridge Handbook of Pragmatics (pp. 251-274). Cambridge: Cambridge University Press.

Haugh, M. (2015). International students and the "English problem" in Australian universities: a discursive perspective. In Abe Ata and Alex Kostogriz (eds.), International Education and Cultural-Linguistic Experiences of International Students in Australia (pp.91-104), Australian Academic Press, Samford Valley, QLD. 
Hecht, M. (2009). Communication theory of identity. In S. Littlejohn and K. Foss (Eds.), Encyclopedia of Communication Theory: Volume 1 (pp.139-141). Thousand Oaks, CA: Sage.

Heinemann, T., \& Traverso, V. (2009). Complaining in interaction. Journal of Pragmatics, 41(12), 2381-2384.

Humphreys, P. Haugh, M, Fenton-Smith, B., Lobo, A., Michael, R., \& Walkinshaw, I. (2012). Tracking international students' English proficiency over the first semester of undergraduate study. IELTS Research Reports Online Series, 2012/1. Retrieved from http://www.ielts.org/pdf/Humphreys2012_ORR.pdf.

Jefferson, G. (1984). On stepwise transition from talk about a trouble to inappropriately nextpositioned matters. In J. M. Atkinson \& J. Heritage (Eds.), Structures of Social Action (pp. 191-222). Cambridge: Cambridge University Press.

Jefferson, G. (1988). On the sequential organization of troubles talk in ordinary conversation. Social Problems, 35(4), 418-441.

Jefferson, G. (2004). Glossary of transcript symbols with an introduction. In G. Lerner (Ed.), Conversation Analysis: Studies from the First Generation (pp. 13-23). Amsterdam: John Benjamins.

Jefferson, G., \& Lee, J. (1981). The rejection of advice: managing the problematic convergence of a 'troubles-telling' and a 'service encounter'. Journal of Pragmatics, 5(5), 399-422.

Krippendorff, K. (2013). Content Analysis: An Introduction to its Methodology ( ${ }^{\text {rd }}$ edn). Thousand Oaks, CA: Sage.

Leder, G., \& Forgasz, H. (2004). Australian and international mature students: the daily challenges. Higher Education Research \& Development, 23(2), 183-198.

Lindström, A., \& Sorjonen, M. (2013). Affiliation in conversation. In J. Sidnell \& T. Stivers (Eds.), The Handbook of Conversation Analysis (pp. 350-369). Malden, MA: WileyBlackwell.

Linton, B., \& Cronau, P. (2015, April 20). Degrees of deception. [Television broadcast]. Canberra, ACU: Australian Broadcasting Corporation.

Murray, N. (2012). Ten ‘Good Practice Principles’ . . . ten key questions: considerations in addressing the English language needs of higher education students. Higher Education Research \& Development, 31(2), 233-246.

O’Loughlin, K., \& Arkoudis, S. (2009). Investigating IELTS exit score gains in higher education. IELTS Research Reports, 10 (Report 3). IELTS Australia. Retrieved from https://www.ielts.org/pdf/Vol10_Report3.pdf.

Phillips, D. (1987). Language proficiency assessment and tertiary entry for non-English speaking students. Journal of Tertiary Educational Administration, 9(1), 77-88.

Robertson, M., Line, M., Jones, S., \& Thomas, S. (2000). International students, learning environments and perceptions: a case study using the Delphi technique. Higher Education Research and Development, 19(1), 89-102.

Robertson, S. (2011). Cash cows, backdoor migrants, or activist citizens? International students, citizenship, and rights in Australia. Ethnic and Racial Studies, 34(12), 21922211. 
Tananuraksakul, N. \& Hall, D. (2011). International students' emotional security and dignity in an Australian context: an aspect of psychological well-being. Journal of Research in International Education, 10(2), 189-200.

Zhang, Y., \& Mi, Y. (2010). Another look at the language difficulties of international students. Journal of Studies in International Education, 14(4), 371-388. 